\title{
Effects of forest width on fish use of fringing mangroves in a highly urbanised tropical estuary
}

\author{
Kimberley Dunbar ${ }^{\mathrm{A}, \mathrm{D}}$, Ronald Baker ${ }^{\mathrm{A}, \mathrm{B}, \mathrm{C}}$ and Marcus Sheaves ${ }^{\mathrm{A}, \mathrm{B}}$ \\ ${ }^{A}$ College of Marine and Environmental Sciences, James Cook University, \\ Townsville, Qld 4811, Australia. \\ ${ }^{B}$ TropWATER, Centre for Tropical Water \& Aquatic Ecosystem Research, \\ James Cook University, Townsville, Qld 4811, Australia. \\ ${ }^{\mathrm{C}}$ CSIRO Land and Water, ATSIP Building, James Cook University, \\ Townsville, Qld 4811, Australia. \\ ${ }^{D}$ Corresponding author: Email: kimberley.dunbar@my.jcu.edu.au
}

\begin{abstract}
The size and shape of a habitat patch can influence patterns of species utilisation. The present study examined how the width of fringing mangrove habitats affects the composition and use patterns of the fish assemblage using mangrove edge habitats on the flooding tide. Underwater cameras surveyed fish approaching mangrove habitats, ranging from a thin fringe $5 \mathrm{~m}$ wide to forests over $75 \mathrm{~m}$ wide, in a highly modified tropical estuary. The fish assemblage composition was similar across all mangrove widths, although the temporal patterns of use varied among mangrove widths for some species. The mean maximum number of individuals in the field of view was similar among mangrove widths, but fish were visible for a significantly greater proportion of time in videos from narrow $(<20 \mathrm{~m})$ than wide $(\geq 20 \mathrm{~m})$ mangrove stands ( $15 v .3 \%$ respectively). At least some fish were visible in the field of view in narrow mangrove fringes throughout the first hour of the flood tide, whereas in wide mangroves areas the presence of fish declined over time. The findings suggest that estuarine fish are using mangrove edge habitat regardless of width, making narrow mangroves viable habitats for estuarine fish.
\end{abstract}

Additional keywords: edge effect, habitat width, mangrove restoration, nursery ground.

Received 28 March 2016, accepted 9 December 2016, published online 1 February 2017

\section{Introduction}

Owing to the continued coastal development occurring around the world, the extent of mangrove forests is steadily decreasing, with mangroves being lost at a rate of $\sim 1 \%$ per year (Valiela et al. 2001). Narrow bands of mangroves are common in developed areas; they are also planted for mangrove and coastal restoration projects, with few mangrove restoration projects able to replant large areas of mangroves. Studies of mangrove fish have rarely examined structural and landscape measures to understand how they drive fish distribution and abundance (Faunce and Serafy 2006). In order to understand the functional value of mangroves not only as fish habitats, but also their contributions to ecosystem productivity and diversity, the inclusion of these variables is necessary (Nagelkerken et al. 2015). An increased understanding of these interrelated variables can improve conservation and restoration programs that aim to maintain diversity and habitat function.

In terrestrial systems, the size and shape of the habitat plays an important role in the value of different habitats for organisms (Collinge 1996; Sinclair et al. 2005; Yletyinen and Norrdahl 2008). Some species are unable to use smaller patch sizes because they provide insufficient resources for the organism, whereas other species prefer to use edge habitats and avoid the central regions of larger patches (Parker and MacNally 2002; King et al. 2009). In contrast with terrestrial systems, there has been little examination of the importance of patch size and habitat width in most marine ecosystems (Jackson et al. 2006). Edge effects have been shown to be important in the distribution of fish and mobile crustaceans in salt marshes (Minello and Rozas 2002; Minello et al. 2008, 2012; Sousa and Dangremond 2011; Trave and Sheaves 2014) and seagrass (Smith et al. 2011), but there is currently no understanding of the importance of patch width on habitat use by fish in mangroves (Faunce and Serafy 2006).

The size and shape of individual habitats can direct the way in which habitats are used by different species (Jackson et al. 2006; Harwell et al. 2011). In seagrass beds, the use of small patches was significantly different from large patches for five of eight taxa, with more juveniles and fewer adults found in smaller patch sizes (Tanner 2006). Small fish may occur in greater density in the centre of seagrass beds and in patches with smaller edge : area ratios because predator encounter rates are greater at patch edges, suggesting that wider patches provide greater refuge (Smith et al. 2011). Although the habitats with smaller edge : area ratios are 
ideal for providing refuge for many prey organisms, habitats with large edge : area ratios are ideal for foraging predators, showing that habitats will not cater equally to all species (Bowden et al. 2001). However, in salt marsh edges in the Gulf of Mexico, a greater abundance of decapod crustaceans was found within $1 \mathrm{~m}$ of the edge (Minello and Rozas 2002), suggesting the edges are of greatest value to the species occupying these areas, highlighting the importance of edge habitat for these taxa (Minello et al. 2008; Haas et. al. 2004; Rozas and Minello 2007). To maximise fishery production of penaeid shrimp, large areas of edge habitat are included in restored salt marshes in the northern Gulf of Mexico (Minello et al. 2012). This highlights the importance of understanding the value of narrow patches of habitats before further loss of remnant patches or restoration efforts occur.

Understanding the value of different width patches is particularly important in the case of mangroves. Their location at the marine-terrestrial interface means they are often affected by the encroachment of urban and agricultural development, and they freely colonise the intertidal edges of waterways created or modified by development. Both situations result in narrow mangrove fringes. Consequently, understanding the value of these narrow fringes is particularly important to underpinning rational decisions on development around coastal waterways. However, the difficulties involved in sampling within a mangrove system (Uncles et al. 1994; Read et al. 2004; Ellis and Bell 2008) have left major gaps in knowledge of the use of mangrove habitats by estuarine fish assemblages. The present study was undertaken to address the lack of understanding of the value of narrow $v$. wide mangrove fringes by assessing the relative utilisation of narrow and broad mangrove forests fringing an urbanised waterway in tropical north-eastern Australia. In particular, we were interested in determining whether there were any substantial differences in the fish assemblages observed along mangrove fringes of different widths that may indicate a difference in functional value of these habitats.

\section{Materials and methods}

Study site

Fish were surveyed in mangrove fringes of Ross Creek, on the north-east coast of tropical Australia (Fig. 1), between May and September 2013. Ross Creek was chosen for the present study because this estuarine system is a highly disturbed urban estuarine environment located in the centre of the city of Townsville in the tropics of northern Queensland, Australia. It is fringed by remnant and regrowth mangrove forests of varying widths, including narrow mangroves, and such areas are becoming increasingly common because of continued coastal development. The regrowth mangrove forests are dominated by Avicennia marina and range in width from a single strip of trees $\sim 5$ - to 75 -m-wide forests (Fig. 1). The full range of mangrove forest widths are represented within a $500-\mathrm{m}$ reach, meaning that fish sampled along the edge of any part of the forest had the opportunity to access forests across the entire range of widths of mangroves present in the system. Surveys of the fish assemblage using mangrove forests of different widths were achieved by point census using underwater video cameras (Oregon Scientific HD, Oregon Scientific, Inc., Hunghorn, Kowloon, Hong Kong S. A. R., China). Cameras were placed $1 \mathrm{~m}$ outside the edge of the mangroves facing inwards towards the

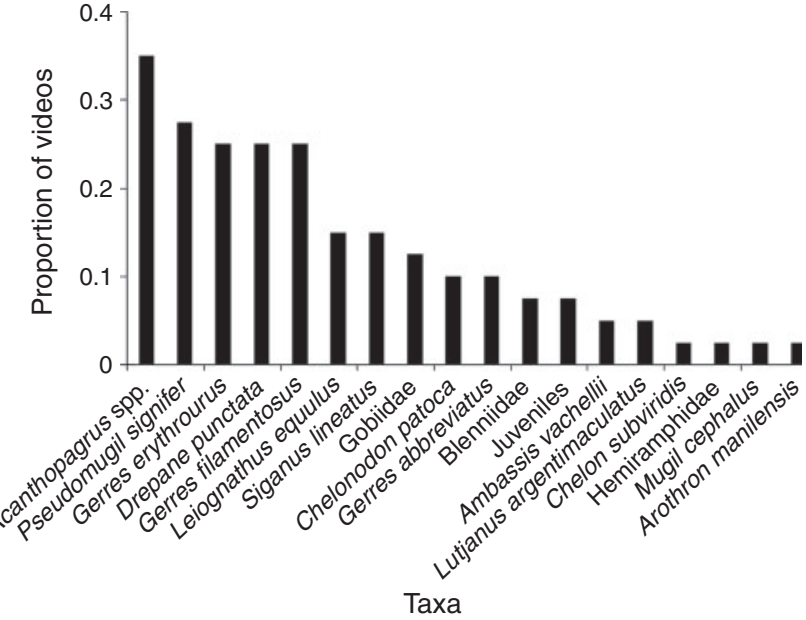

Fig. 1. Proportion of videos from Ross Creek, Australia, in which each fish species was present. Proportions are based on the 40 videos containing fish (of a total of 52 videos).

edge of the forest. The mangrove edge was defined as the boundary between $A$. marina pneumatophores and bare substrate lower in the intertidal zone. Sampling was conducted in daylight hours (0600-1700 hours) during neap tides (high tides $<3 \mathrm{~m}$ ), because this provided the greatest visibility due to a low level of tidal movement minimising sediment resuspension. The region has semidiurnal tides with a maximum range of $4 \mathrm{~m}$, with $\sim 6 \mathrm{~h}$ between high and low tide. Mangrove forest edge begins to flood at $\sim 1.1 \mathrm{~m}$, which, on the neap tides sampled, is $\sim 30-45$ min after the beginning of the flood tide. Cameras were deployed on the incoming tide when the water depth was $\sim 5-10 \mathrm{~cm}$ above the top of the camera, or $\sim 12-17 \mathrm{~cm}$ deep. The mangroves were filmed for the next hour, ending at approximately one-third of the way through the flood tide. This meant that sampling commenced soon after the tide first flooded the mangroves and when a variety of fish species could gain access to the mangroves. The minimum acceptable visibility for the present study was $1 \mathrm{~m}$, ensuring the pneumatophores were visible. This corresponded to the substrate being clearly visible from the boat in $30 \mathrm{~cm}$ of water, and sampling was only commenced under these conditions. Turbidity was relatively consistent for all sampling occasions with maximum visibility never exceeding $1.2 \mathrm{~m}$. On any given sampling occasion, cameras were deployed a minimum of $5 \mathrm{~m}$ apart to ensure independence, and distributed within the sampling reach to represent the range of mangrove widths available to fish. Because of the extent of available habitat, an uneven number of replicate videos was collected from different mangrove width categories (Table 1). The cameras recorded for between 1 and $2 \mathrm{~h}$, depending on battery life and memory capacity. The 52 camera drops across the mangrove widths produced over $50 \mathrm{~h}$ of usable video footage for analysis. Camera locations were marked using a global positioning system (GPS), and the mangrove width determined using Google Earth (https://www. google.com/earth/, accessed 13 April 2013), with ground truthing used to confirm the remote-sensed estimates.

The mangrove widths were grouped into width categories at two scales: (1) 10-m intervals from 0 through to $>50 \mathrm{~m}$; and then 
Table 1. Number of replicate camera censuses for different mangrove widths

\begin{tabular}{lc}
\hline $\begin{array}{l}\text { Mangrove } \\
\text { width }(\mathrm{m})\end{array}$ & $\begin{array}{c}\text { Number of replicate } \\
\text { camera censuses }\end{array}$ \\
\hline$\leq 10$ & 13 \\
$>10-20$ & 11 \\
$>20-30$ & 14 \\
$>30-40$ & 5 \\
$>40-50$ & 5 \\
$>50$ & 4 \\
\hline
\end{tabular}

(2) more broadly as narrow $(<20 \mathrm{~m})$ or wide $(\geq 20 \mathrm{~m})$. The division of wide and narrow at $20 \mathrm{~m}$ was based on a survey of mangrove stands in developed estuaries in Australia using Google Earth ( $n=68$ estuaries), which found mangrove banks along urbanised estuaries to be typically less than $20 \mathrm{~m}$ wide, making $20 \mathrm{~m}$ a practical division for management. Owing to the variation in video lengths, only the first hour of video was used in analysis to allow direct comparison with standardised time for each video replicate. Fish species were identified from the videos by the lead author (K. Dunbar), with any uncertain identification confirmed by experienced researchers familiar with the estuarine fish of the region. Smaller juveniles of Acanthopagrus pacificus and Acanthopagrus australis were not always clearly distinguishable, and hence these species were grouped as Acanthopagrus spp. for analysis. Some individuals were not able to be categorised to the species or genus level, and so were grouped into families. An additional category of 'juveniles' was created to cover those fish that were obviously juveniles based on size and colouration but were too small to be able to be identified accurately. All other taxa were identified to species level. For the present study, fish observed on the edge of the mangroves are considered to be using the edge of mangrove forest and are hence considered to be using the mangrove habitat.

The start and end time of each occasion that at least one fish of each taxon appeared on the screen was recorded to enable the total time in camera for each taxon to be calculated. The maximum number of individuals present of each taxon during each of these occasions was also recorded, allowing the maximum number of individuals (nMax) for each species per video to be determined, as well as the nMax for all fish regardless of species. These data were summarised as mean values across all videos within each mangrove width class. A $t$-test was conducted using SPSS, ver. 19.0 (IBM Corp., Chicago, IL, USA) to determine whether significant differences were present between wide and narrow mangroves for both the mean proportion of time fish were in front of the cameras and the nMax present in the field of view of the camera.

For the two dominant taxa seen most frequently in the videos, Pseudomugil signifer and Acanthopagrus spp., the proportion of time each taxon was present for each 10-min segment of videos was calculated to determine temporal patterns of utilisation over the course of the first hour of tidal influx to the mangroves.

\section{Results}

Video analysis revealed 17 taxa, as well as juvenile fish that could not be confidently identified, giving a total of 18 groups
Table 2. Fish assemblage composition along the lower edge of mangroves of different widths in Ross Creek, Townsville (QId, Australia) ' $\mathrm{X}$ ' indicates species presence. Species are listed in order from most to least frequently occurring (Fig. 2), with numbers in parenthesis after species names indicating the number of videos (of 52 in total: 24 in narrow mangroves and 28 in wide mangroves) each species was observed in

\begin{tabular}{lcccccc}
\hline Taxon & \multicolumn{5}{c}{ Mangrove forest width (m) } \\
& $\leq 10>10-20>20-30>30-40>40-50>50$ \\
\hline Acanthopagrus spp. (14) & & X & X & X & X \\
Pseudomugil signifer (11) & X & X & X & X & & X \\
Gerres erythrourus (10) & & X & X & & X & X \\
Drepane punctata (10) & X & & X & X & & X \\
Gerres filamentosus (10) & X & X & X & & X & X \\
Leiognathus equulus (6) & & X & & X & & X \\
Siganus lineatus (6) & & & X & X & X & \\
Gobiidae (5) & X & & X & & & X \\
Chelonodon patoca (4) & X & X & X & & & \\
Gerres abbreviates (4) & X & X & & X & & \\
& & & & & &
\end{tabular}

using the fringing mangroves in Ross Creek. Of these, four taxa appeared in only a single video each, and only eight appeared in more than five videos. Acanthopagrus spp. and $P$. signifer were present in the greatest mean proportion of videos (mean 0.31 ; Fig. 1).

When mangrove habitat use was investigated at an assemblage level, no consistent pattern was observed, with the more common species (present in five or more videos) occurring across the range of forest widths (Table 2). Of the 18 taxa, 13 were present in mangrove stands $\leq 20 \mathrm{~m}$ wide, and 15 were present in the wider mangroves.

Fish were present in the field of view for a greater proportion of time in narrower than in wider mangroves $\left(t_{2,32}=3.6524\right.$, $P<0.001$ ) (Fig. 2a). There was a decline in fish present in the field of view over the first three widths, followed by approximately stable low levels, showing fish remained within the field of view around narrow mangroves for longer than at wide mangroves. The mean nMax present in a single frame per video varied from $\sim 4$ to 10 individuals among mangrove widths, with a high degree of variability in all widths except the narrowest category, with no significant difference between wide and narrow mangroves $\left(t_{2,32}=0.0391, P=0.969\right.$; Fig. $2 b$ ). The actual nMax found in a single frame was 27 , and these were unidentified juveniles along the fringe of a 20to 30 -m-wide mangrove forest.

The two most commonly occurring taxa, namely Acanthopagrus spp. and $P$. signifer, exhibited contrasting patterns of occurrence through time (Fig. 3). P. signifer were present for the highest proportion of time in the first $10 \mathrm{~min}$ of video along the front edge of both wide and narrow mangroves (Fig. 3a), with a gradual decline over the following hour. They were consistently present for a greater proportion of time in narrow than wide mangroves. In contrast, Acanthopagrus spp. arrived later, with their peak occurrence between 20 and $50 \mathrm{~min}$ after the commencement of filming (Fig. $3 b$ ). This was consistent for both narrow and wide mangroves, but these fish were present for a greater proportion of time in wide than narrow mangrove edges. 

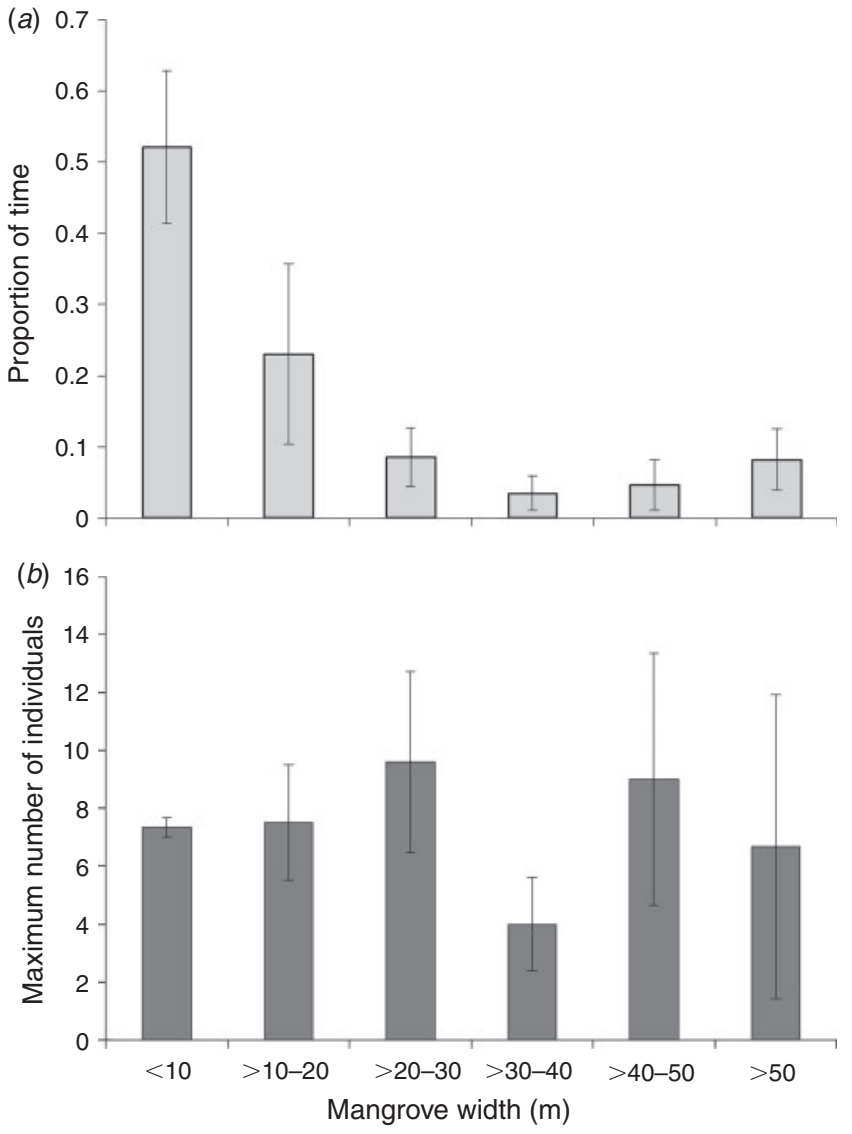

Fig. 2. (a) Proportion of time fish spent in front of the camera and (b) maximum number of individuals in the field of view in different mangrove widths in Ross Creek, Australia. Data are the mean \pm s.e.m.

\section{Discussion}

Given the continued loss of mangroves around the globe (Valiela et al. 2001) and the increasing number of restoration efforts (Lewis 2000), understanding the relative values of different habitat configurations is essential (Minello et al. 2012). Although only performed on a small scale, the present study is the first to directly compare fish assemblages using mangrove edge habitats in forests of different widths, and so provides an important step towards improved management of these systems. A variety of common taxa made use of mangrove habitats across the full spectrum of forest widths examined, and some species are likely to be moving well into the mangrove forests (Sheaves et al. 2016). These findings suggest that the narrow fringes of mangrove trees provided broadly equivalent habitat value to broad mangrove fringes for these fish. The study site comprised a single 500-m reach that contained fringing forests spanning all widths examined. This means that each individual fish observed had the opportunity to access both narrow and wide mangrove fringes, providing a robust comparison of fish assemblages using forests of different widths.

Some of the species observed using mangroves remain within mangrove and estuarine systems their whole life (e.g. P. signifer; Wong et al. 2004), whereas others travel between marine systems, including reefs and the estuarine systems (e.g. Siganus

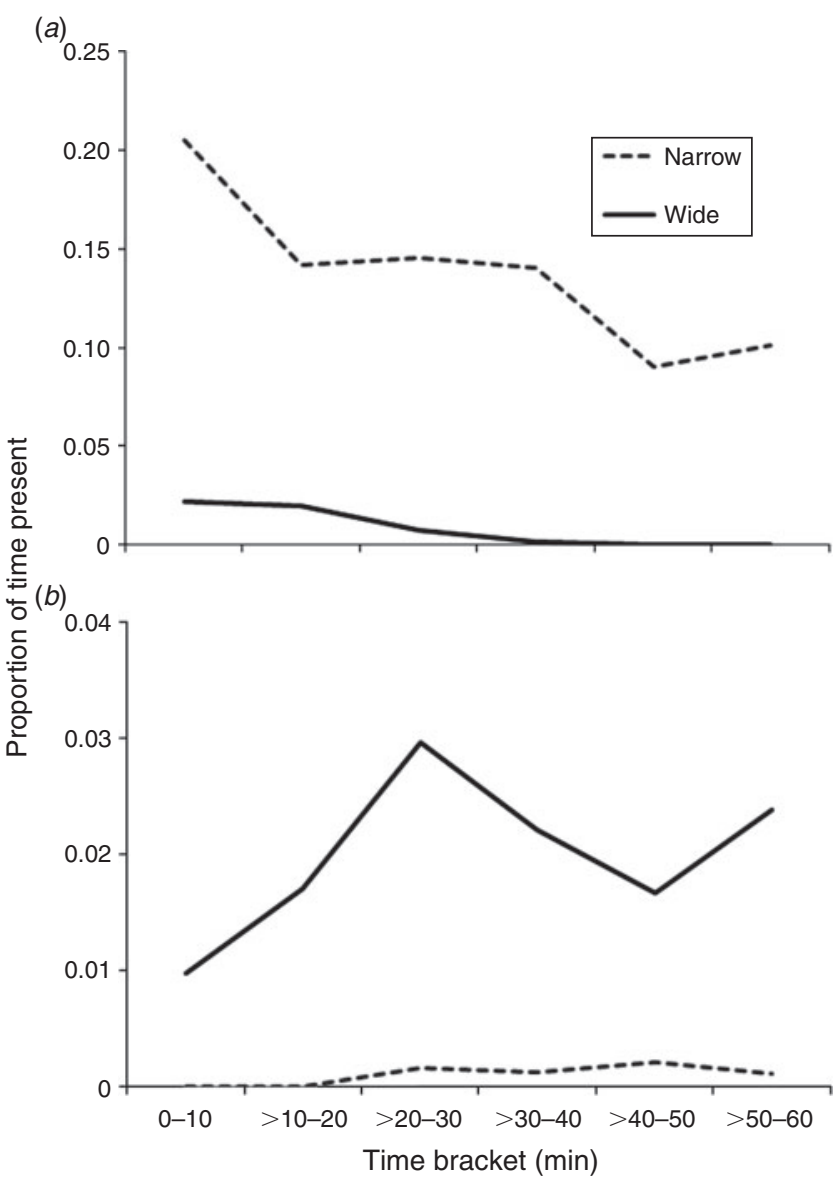

Fig. 3. Overall proportion of time spent in video by (a) Pseudomugil signifer and (b) Acanthopagrus spp. in wide $(\geq 20 \mathrm{~m})$ and narrow $(<20 \mathrm{~m})$ mangroves during the first hour of the flood tide in Ross Creek, Australia.

lineatus; Blaber et al. 1989; Sheaves 1992; Kuriiwa et al. 2007). The common species observed in the present study are typical of those reported from estuarine systems throughout the region (Blaber et al. 1989; Robertson and Duke 1990; Sheaves 2006). Although the fish assemblage used the full range of mangrove widths, some species showed particular patterns of use. As found, $P$. signifer was predominantly in habitats less than $25 \mathrm{~m}$ wide, although there was an occasional appearance in areas of greater width.

The higher mean time spent in front of the camera in narrow compared with wide mangroves could indicate that, in fact, more fish use narrow mangroves. However, the mean numbers of individuals visible in the field of view was similar among mangrove widths, suggesting that fish moving into narrow mangroves stay visible along the edge for longer rather than more individuals moving into these habitats. This could be an accumulation effect whereby fish in a compressed area have less space to spread out and so are focused in a smaller area, therefore appearing in the videos more frequently. In all mangrove widths, fish occurrence peaked in the first $20 \mathrm{~min}$. Together, these findings suggest that fish move into both narrow and wide mangroves quickly with the flooding tide and that they subsequently penetrate further into the forest where possible. 
Several possible benefits have been postulated to explain fish use of mangroves (Al-Khayat and Jones 1999; Nagelkerken and Faunce 2008). The edge of both narrow and wider mangroves could provide equivalent hydrodynamic benefit to fish, because current flow decreases significantly within as little as $0.5 \mathrm{~m}$ from the edge of structured habitats, including mangroves and seagrass beds (Warry et al. 2009). Similarly, a small amount of structure along the edge may be all that is needed to provide sufficient refuge from predators for prey fish species, meaning that narrow mangroves may be sufficient to fulfil the needs of any fish that use mangrove structures for protection (MacDonald et al. 2009). In addition, although wider mangrove forests may provide a large area of potential habitat, oxygen levels deeper within the forest may rapidly become depleted because of bacterial breakdown of detrital material (Mazda et al. 1990; Wolanski et al. 1992). Consequently, many parts of larger mangrove forests may not be suitable for fish occupation for much of the time (Cooper et al. 2002; Knight et al. 2013).

There is some direct evidence of fish feeding in mangrove habitats (Sheaves and Molony 2000). Foraging efficiency is proposed to be greater on mudflats outside of mangroves than within the mangrove areas (Tse et al. 2008). This suggests that although few estuarine fish appear to forage within the mangrove forests, those that do make more extensive use of this habitat may well use it as an important feeding area. As such, the relative value of wide and narrow mangroves as a foraging habitat to fish should be investigated further.

Water depth is an important factor regulating fish movements in intertidal habitats (Meager et al. 2003; Nagelkerken and Faunce 2008). Some fish species enter the mangroves with the start of the flooding tide and remain along the very edges of the water regardless of how far into the mangroves the water penetrates, tracking the shallow water rather than using the mangroves per se (Paterson and Whitfield 2000; Krumme and Saint-Paul 2003). Other species may only move into the mangroves later in the tide when the forest is flooded to greater depths (Meynecke et al. 2008), suggesting that water depth may be a driving factor affecting the use of mangroves by different fish species.

In the present study, $P$. signifer appears to have tracked the shallow water edge through the forest. These fish appeared rapidly once the forest flooded and declined through time, particularly in the wider mangroves. In contrast, Acanthopagrus spp. appeared a little later in the flood tide and then remained within the field of view of the camera for consistently high periods of time. These deeper-bodied fish arrive once the water depth is sufficient and then remain around the mangrove habitat as the tide continues to rise. Further studies in a broader range of areas are needed to fully separate the effects of water depth and mangrove forest width on fish usage of these habitats.

Understanding the functional values of different habitat configurations is particularly important for mangrove restoration projects, and further studies are required to determine optimum sizes and widths of mangroves to be planted. Other intertidal ecosystems, such as salt marshes in America, have been undergoing restoration for many years through terracing, a process that produces a high edge : area ratio of restored marsh and should maximise production of fishery species (Minello et al. 2012). Although there is a higher growth rate of nekton in terraced marshes than in the open ponds they are replacing (Rozas and Minello 2009), fish densities are still lower than in natural marshes (Minello and Webb 1997), indicating that thin strips of habitat in terraces are not necessarily functionally equivalent in all respects to natural marshes (Rozas and Minello 2001). Further studies may prove the same to be true for mangroves.

Developments that result in the loss of habitat frequently attempt to offset this loss by creating or protecting equivalent habitat elsewhere. It is of great concern in these cases whether the new habitat is of truly equivalent functional value to the habitat removed (Lewis 2000). When environmental offsets are planned, not only does the area of the mangroves to be removed from development sites need to be considered, but also the habitat's shape. The data gathered in the present study are a step towards more comprehensively determining the value of wide and narrow mangroves as functional habitats, and how these fit into the broader seascape to structure fish assemblages (Sheaves 2009). Future studies should examine assemblage-level patterns among trophic and other functional groups (sensu Elliott et al. 2007) to uncover potential drivers of mangrove value and any differences in the importance of wide and narrow mangroves to fish. A detailed examination of habitat usage patterns compared across different tidal cycles (sensu Ellis and Bell 2008), as well as a comparison of wide and narrow mangrove usage compared with bare banks and rock walls, can provide further information regarding mangrove use by fish.

The present study found that narrow mangroves were used by fish. If this utilisation is shown to be functionally useful for fish, the major effects caused by the loss of these habitats may not be evident until the final fringes are lost. If this is the case, thin remnant fringes could be extremely valuable habitats, and the depletion of these narrow bands could have broad consequences for nursery ground functions and the support of fisheries. A clear understanding of the importance of different mangrove widths and configurations within the seascape is critical for determining the best methods to mitigate damage and changes to the ecosystem, and to thus maintain ecosystem function into the future.

\section{Acknowledgements}

The authors thank Matthew Ireland and Michael Bradley for assistance with field work and Ross Johnston for guidance, advice and field work assistance. This study was funded, in part, by the College of Marine and Environmental Sciences at James Cook University (JCU), and formed part of the Honours research project of Kimberley Dunbar. Ron Baker was supported, in part, by a Research Fellowship from the Tropical Landscapes Joint Venture between JCU and CSIRO.

\section{References}

Al-Khayat, J. A., and Jones, D. A. (1999). A comparison of the macrofauna of natural and replanted mangroves in Qatar. Estuarine, Coastal and Shelf Science 49(Suppl. 1), 55-63. doi:10.1016/S0272-7714(99)80009-2

Blaber, S. J. M., Brewer, D. T., and Salini, J. P. (1989). Species composition and biomasses of fishes in different habitats of a tropical Northern Australian estuary: their occurrence in the adjoining sea and estuarine dependence. Estuarine, Coastal and Shelf Science 29, 509-531. doi:10.1016/0272-7714(89)90008-5

Bowden, D. A., Rowden, A. A., and Attrill, M. J. (2001). Effect of patch size and in-patch location on the infaunal macroinvertebrate assemblages of 
Zostera marina seagrass beds. Journal of Experimental Marine Biology and Ecology 259, 133-154. doi:10.1016/S0022-0981(01)00236-2

Collinge, S. K. (1996). Ecological consequences of habitat fragmentation: implications for landscape architecture and planning. Landscape and Urban Planning 36, 59-77. doi:10.1016/S0169-2046(96)00341-6

Cooper, R. U., Clough, L. M., Farwell, M. A., and West, T. L. (2002). Hypoxia-induced metabolic and antioxidant enzymatic activities in the estuarine fish Leiostomus xanthurus. Journal of Experimental Marine Biology and Ecology 279, 1-20. doi:10.1016/S0022-0981(02)00329-5

Elliott, M., Whitfield, A. K., Potter, I. C., Blaber, S. J. M., Cyrus, D. P., Nordlie, F. G., and Harrison, T. D. (2007). The guild approach to categorizing estuarine fish assemblages: a global review. Fish and Fisheries 8, 241-268. doi:10.1111/J.1467-2679.2007.00253.X

Ellis, W., and Bell, S. (2008). Tidal influence on a fringing mangrove intertidal fish community as observed by in situ video recording: implications for studies of tidally migrating nekton. Marine Ecology Progress Series 370, 207-219. doi:10.3354/MEPS07567

Faunce, C. H., and Serafy, J. E. (2006). Mangroves as fish habitat: 50 years of field studies. Marine Ecology Progress Series 318, 1-18. doi:10.3354/ MEPS318001

Haas, H. L., Rose, K. A., Fry, B., Minello, T. J., and Rozas, L. P. (2004). Brown shrimp on the edge: linking habitat to survival using an individualbased simulation model. Ecological Applications 14, 1232-1247. doi:10.1890/03-5101

Harwell, H. D., Posey, M. H., and Alphin, T. D. (2011). Landscape aspects of oyster reefs: effects of fragmentation on habitat utilization. Journal of Experimental Marine Biology and Ecology 409, 30-41. doi:10.1016/ J.JEMBE.2011.07.036

Jackson, E. L., Attrill, M. J., Rowden, A. A., and Jones, M. B. (2006). Seagrass complexity hierarchies: influence on fish groups around the coast of Jersey (English Channel). Journal of Experimental Marine Biology and Ecology 330, 38-54. doi:10.1016/J.JEMBE.2005.12.016

King, D. I., Chandler, R. B., Collins, J. M., Petersen, W. R., and Lautzenheiser, T. E. (2009). Effects of width, edge and habitat on the abundance and nesting success of scrub-shrub birds in powerline corridors. Biological Conservation 142, 2672-2680. doi:10.1016/J.BIO CON.2009.06.016

Knight, J. M., Griffin, L., Dale, P. E. R., and Sheaves, M. (2013). Short-term dissolved oxygen patterns in sub-tropical mangroves. Estuarine, Coastal and Shelf Science 131, 290-296. doi:10.1016/J.ECSS.2013.06.024

Krumme, U., and Saint-Paul, U. (2003). Observations of fish migration in a macrotidal mangrove channel in Northern Brazil using a 200-kHz splitbeam sonar. Aquatic Living Resources 16, 175-184. doi:10.1016/S09907440(03)00046-9

Kuriiwa, K., Hanzawa, N., Yoshino, T., Kimura, S., and Nishida, M. (2007). Phylogenetic relationships and natural hybridization in rabbitfishes (Teleostei: Siganidae) inferred from mitochondrial and nuclear DNA analyses. Molecular Phylogenetics and Evolution 45, 69-80. doi:10.1016/ J.YMPEV.2007.04.018

Lewis, R. R., III (2000). Ecologically based goal setting in mangrove forest and tidal marsh restoration. Ecological Engineering 15, 191-198. doi:10.1016/S0925-8574(00)00070-7

MacDonald, J. A., Shahrestani, S., and Weis, J. S. (2009). Behavior and space utilization of two common fishes within Caribbean mangroves: implications for the protective function of mangrove habitats. Estuarine, Coastal and Shelf Science 84, 195-201. doi:10.1016/J.ECSS. 2009.06.010

Mazda, Y., Sato, Y., Sawamoto, S., Yokochi, H., and Wolanski, E. (1990). Links between physical, chemical and biological processes in Bashitaminato, a mangrove swamp in Japan. Estuarine, Coastal and Shelf Science 31, 817-833. doi:10.1016/0272-7714(90)90085-6

Meager, J. J., Vance, D. J., Williamson, I., and Loneragan, N. R. (2003). Microhabitat distribution of juvenile Penaeus merguiensis de Man and other epibenthic crustaceans within a mangrove forest in subtropical
Australia. Journal of Experimental Marine Biology and Ecology 294, 127-144. doi:10.1016/S0022-0981(03)00241-7

Meynecke, J., Poole, G. C., Werry, J., and Lee, S. Y. (2008). Use of PIT tag and underwater video recording in assessing estuarine fish movement in a high intertidal mangrove and salt marsh creek. Estuarine, Coastal and Shelf Science 79, 168-178. doi:10.1016/J.ECSS.2008.03.019

Minello, T. J., and Rozas, L. P. (2002). Nekton in gulf coast wetlands: finescale distributions, landscape patterns, and restoration implications. Ecological Applications 12, 441-455. doi:10.1890/1051-0761(2002) 012[0441:NIGCWF]2.0.CO;2

Minello, T. J., and Webb, J. W. (1997). Use of natural and created Spartina alterniflora salt marshes by fisheries species and other aquatic fauna in Galveston Bay, Texas, USA. Marine Ecology Progress Series 151, 165-179. doi:10.3354/MEPS151165

Minello, T. J., Matthews, G. A., Caldwell, P. A., and Rozas, L. P. (2008) Population and production estimates for decapod crustaceans in wetlands of Galveston Bay, Texas. Transactions of the American Fisheries Society 137, 129-146. doi:10.1577/T06-276.1

Minello, T. J., Rozas, L. P., Caldwell, P. A., and Liese, C. (2012). A comparison of salt marsh construction costs with the value of exported shrimp production. Wetlands 32, 791-799. doi:10.1007/S13157-011-0237-9

Nagelkerken, I., and Faunce, C. H. (2008). What makes mangroves attractive to fish? Use of artificial units to test the influence of water depth, cross-shelf location, and presence of root structure. Estuarine, Coastal and Shelf Science 79, 559-565. doi:10.1016/J.ECSS.2008.04.011

Nagelkerken, I., Sheaves, M., Baker, R., and Connolly, R. (2015). The seascape nursery: a novel spatial approach to identify and manage nurseries for coastal marine fauna. Fish and Fisheries 16, 362-371. doi:10.1111/FAF.12057

Parker, M., and Mac Nally, R. (2002). Habitat loss and the habitat fragmentation threshold: an experimental evaluation of impacts on richness and total abundances using grassland invertebrates. Biological Conservation 105, 217-229. doi:10.1016/S0006-3207(01)00184-7

Paterson, A. W., and Whitfield, A. K. (2000). Do shallow-water habitats function as refugia for juvenile fishes? Estuarine, Coastal and Shelf Science 51, 359-364. doi:10.1006/ECSS.2000.0640

Read, M. A., Miller, J. D., Bell, I. P., and Felton, A. (2004). The distribution and abundance of the estuarine crocodile, Crocodylus porosus, in Queensland. Wildlife Research 31, 527-534. doi:10.1071/WR02025

Robertson, A. I., and Duke, N. C. (1990). Mangrove fish-communities in tropical Queensland, Australia: spatial and temporal patterns in densities, biomass and community structure. Marine Biology 104, 369-379. doi:10.1007/BF01314339

Rozas, L. P., and Minello, T. J. (2001). Marsh terracing as a wetland restoration tool for creating fishery habitat. Wetlands 21, 327-341. doi:10.1672/0277-5212(2001)021[0327:MTAAWR]2.0.CO;2

Rozas, L. P., and Minello, T. J. (2007). Restoring coastal habitat using marsh terracing: the effect of cell size on nekton use. Wetlands 27, 595-609. doi:10.1672/0277-5212(2007)27[595:RCHUMT]2.0.CO;2

Rozas, L. P., and Minello, T. J. (2009). Using nekton growth as a metric for assessing habitat restoration by marsh terracing. Marine Ecology Progress Series 394, 179-193. doi:10.3354/MEPS08274

Sheaves, M. (1992). Patterns of distribution and abundance of fishes in different habitats of a mangrove-lined tropical estuary, as determined by fish trapping. Marine and Freshwater Research 43, 1461-1479. doi:10.1071/MF9921461

Sheaves, M. (2006). Scale-dependent variation in composition of fish fauna among sandy tropical estuarine embayments. Marine Ecology Progress Series 310, 173-184. doi:10.3354/MEPS310173

Sheaves, M. (2009). Consequences of ecological connectivity: the coastal ecosystem mosaic. Marine Ecology Progress Series 391, 107-115. doi:10.3354/MEPS08121

Sheaves, M., and Molony, B. (2000). Short-circuit in the mangrove food chain. Marine Ecology Progress Series 199, 97-109. doi:10.3354/MEPS199097 
Sheaves, M., Johnston, R., and Baker, R. (2016). Use of mangroves by fish: new insights from in-forest videos. Marine Ecology Progress Series 549 , 167-182. doi:10.3354/MEPS11690

Sinclair, K. E., Hess, G. R., Moorman, C. E., and Mason, J. H. (2005). Mammalian nest predators respond to greenway width, landscape context and habitat structure. Landscape and Urban Planning 71, 277-293. doi:10.1016/S0169-2046(04)00082-9

Smith, T. M., Hindell, J. S., Jenkins, G. P., Connolly, R. M., and Keough, M. J. (2011). Edge effects in patchy seagrass landscapes: the role of predation in determining fish distribution. Journal of Experimental Marine Biology and Ecology 399, 8-16. doi:10.1016/J.JEMBE.2011. 01.010

Sousa, W. P., and Dangremond, E. M. (2011). Volume.04 - Trophic interactions in coastal and estuarine mangrove forest ecosystems. In 'Treatise on Estuarine and Coastal Science'. (Eds E. Wolanski and D. McLusky.) pp. 43-93. (Academic Press: Waltham, MA, USA.)

Tanner, J. E. (2006). Landscape ecology of interactions between seagrass and mobile epifauna: the matrix matters. Estuarine, Coastal and Shelf Science 68, 404-412. doi:10.1016/J.ECSS.2006.01.029

Trave, C., and Sheaves, M. (2014). Ecotone analysis: assessing the impact of vehicle transit on saltmarsh crab population and ecosystem. Environmental Sciences 3, 655-664.

Tse, P., Nip, T. H. M., and Wong, C. K. (2008). Nursery function of mangrove: a comparison with mudflat in terms of fish species composition and fish diet. Estuarine, Coastal and Shelf Science 80, 235-242. doi:10.1016/J.ECSS.2008.08.002
Uncles, R. J., Barton, M. L., and Stephens, J. A. (1994). Seasonal variability of fine-sediment concentrations in the turbidity maximum region of the Tamar estuary. Estuarine, Coastal and Shelf Science 38, 19-39. doi:10.1006/ECSS.1994.1002

Valiela, I., Bowen, J. L., and York, J. K. (2001). Mangrove forests: one of the world's threatened major tropical environments. Bioscience 51, 807-815. doi:10.1641/0006-3568(2001)051[0807:MFOOTW]2.0.CO;2

Warry, F. Y., Hindell, J. S., Macreadie, P. I., Jenkins, G. P., and Connolly, R. M. (2009). Integrating edge effects into studies of habitat fragmentation: a test using meiofauna in seagrass. Oecologia 159, 883-892. doi:10.1007/ S00442-008-1258-9

Wolanski, E., Mazda, Y., and Ridd, P. (1992). Mangrove hydrodynamics. In 'Tropical Mangrove Ecosystems'. (Eds A. I. Robertson and D. M. Alongi.) pp. 43-62. (American Geophysical Union: Washington, DC, USA.)

Wong, B. B. M., Keogh, J. S., and McGlashan, D. J. (2004). Current and historical patterns of drainage connectivity in eastern Australia inferred from population genetic structuring in a widespread freshwater fish Pseudomugil signifer (Pseudomugilidae). Molecular Ecology 13, 391-401. doi:10.1046/J.1365-294X.2003.02085.X

Yletyinen, S., and Norrdahl, K. (2008). Habitat use of field voles (Microtus agrestis) in wide and narrow buffer zones. Agriculture, Ecosystems \& Environment 123, 194-200. doi:10.1016/J.AGEE.2007.06.002 